\title{
Deltamethrin Induces Apoptosis in Cerebrum Neurons of Quail via Promoting Endoplasmic Reticulum Stress and Mitochondrial Dysfunction
}

Pengfei Wu ( $1765793302 @ q q . c o m)$

Northeast Agricultural University

Bing Han

Northeast Agricultural University

Qingyue Yang

Northeast Agricultural University

Siyu Li

Northeast Agricultural University

Xiaoqiao Wang

Northeast Agricultural University

Jiayi Li

Northeast Agricultural University

Ning Deng

Northeast Agricultural University

Biqi Han

Northeast Agricultural University

Yuge Liao

Northeast Agricultural University

Zhigang Zhang

Northeast Agricultural University

\section{Research Article}

Keywords: Deltamethrin, Quail, Cerebrum neurons, Endoplasmic reticulum stress, Mitochondria dysfunction, Apoptosis

Posted Date: September 7th, 2021

DOI: https://doi.org/10.21203/rs.3.rs-808891/v1

License: (c) (1) This work is licensed under a Creative Commons Attribution 4.0 International License.

Read Full License 


\section{Abstract}

Deltamethrin (DLM) is a widely used and highly effective insecticide. DLM exposure is harmful to animal and human. Quail, as a bird model, has been widely used in the toxicology field. However, there is little information available in the literature about quail cerebrum damage caused by DLM. Here, we investigated the effect of DLM on quail cerebrum neurons. Four groups of healthy quails were assigned (10 quails in each group), respectively given $0,15,30$, and $45 \mathrm{mg} / \mathrm{kg}$ DLM by gavage for 12 weeks. Through the measurements of quail cerebrum, it was found that DLM exposure induced obvious histological changes, oxidative stress, and neurons apoptosis. To further explore the possible molecular mechanisms, we performed real-time quantitative PCR to detect the expression of endoplasmic reticulum (ER) stress-related mRNA. In addition, we detected ATP content in quail cerebrum to evaluate the functional status of mitochondria. The study showed that DLM exposure significantly increased the expression of ER stress-related mRNA and decreased ATP content in quail cerebrum. These results suggest that chronic exposure to DLM induces apoptosis of quail cerebrum neurons via promoting ER stress and mitochondrial dysfunction. Furthermore, our results provide a novel explanation for DLMinduced apoptosis of avian cerebrum neurons.

\section{Introduction}

Deltamethrin (DLM) is a kind of type II synthetic pyrethroids, which is used to drive or kill arthropods, such as flies, ticks, lice, and some mites (Li et al., 2021; Mehlhorn et al., 2017). Among pyrethroids, DLM is considered the safest available insecticide (de Alvarenga et al., 2012). However, numerous recent reports indicate that DLM is an environmental and industrial pollutant and it is toxic to non-aimed organisms living in the same ecosystem (Chen et al., 2016; Jiang et al., 2021). DLM can induce neurotoxicity in many species including human, and DLM exposure is related to neurodegenerative diseases (Quindroit et al., 2021; Saoudi et al., 2017).

Endoplasmic reticulum(ER) is one of the membrane organelles in eukaryotic cells, integrating a variety of functions such as regulation of calcium $\left(\mathrm{Ca}^{2+}\right)$, synthesis and maturation of proteins, biosynthesis of lipids, and maintenance of cell homeostasis (So, 2019). ER stress, as a protective stress response in eukaryotic cells, can be activated by the imbalanced homeostasis (Han et al., 2020a). Once ER stress arises, excessive improperly folded proteins accumulate in the ER lumen (Yilmaz et al., 2017). The unfolded protein response (UPR) then occurs, which is sensed and activated by three transmembrane proteins, activating transcription factor 6 (ATF6), inositol requiring enzyme (IRE), and protein kinase RNA (PKR)-like ER kinase (PERK) (Pluquet and Abbadie, 2021). URP plays a crucial role in the restoration of ER homeostasis. However, if ER stress is sustained or serious, UPR will trigger apoptosis (Ma et al., 2018). Mitochondria, as essential organelles in cells, play a vital role in energy production and calcium homeostasis regulation. More importantly, mitochondria is the regulatory center of apoptosis, controlling apoptosis via releasing Cytochrome $\mathrm{C}$ (Cyt $\mathrm{C}$ ), activating cysteine proteases, changing calcium flux, decreasing ATP pool, and producing excess reactive oxygen species (ROS) (Sun et al., 2021). The mitochondrial pathway, one of the classic apoptotic pathways, is easily activated by numerous stimuli, 
thereby inducing apoptosis (Smith and Gallo, 2018; Yang et al., 2020c). Mitochondria and ER are important target organelles for studying apoptosis and they are closely related to cell survival (Zhong et al., 2018).

As a crucial part of cerebrum, neuron is the most basic structure and function unit of nervous system. Neuronal damage is a crucial mechanism of neurological diseases (Khalatbary et al., 2015). According to report, DLM can increase the risk of Parkinson's disease, learning disabilities, and Alzheimer's disease (Ogaly et al., 2015). DLM interacts with cell $\mathrm{Na}^{+}$channels causing an increase of intracellular $\mathrm{Ca}^{2+}$ and activation of the ER stress pathway (Hossain et al., 2011). Simultaneously, high concentration of $\mathrm{Ca}^{2+}$ might trigger mitochondrial permeability transition pore opening (Miranda-Silva, et al., 2020). Cyt C, apoptosis-inducing factor (AIF) and other apoptotic factors enter the cytoplasm through the open mitochondrial permeability transition pore. Cyt $\mathrm{C}$ and AIF activate the caspase pathway causing apoptosis (Zhou et al., 2020).

However, there may be a connection between mitochondrial apoptotic pathway and ER stress apoptotic pathway, which makes them jointly involved in apoptosis process. DLM-induced neuronal apoptosis in rats, mice, fish, and insects has been reported (Arslan et al., 2017; Gutiérrez et al., 2016; Hossain et al., 2020). However, there are few studies on DLM-induced quail neuron apoptosis, and the specific mechanism of DLM-induced neuronal apoptosis remains unclear.

In this study, we aim to investigate the effect of long-term DLM exposure on neurons of quail cerebrum, and explore the role of ER stress and mitochondrial dysfunction in the progress of quail neuronal apoptosis. We hope to provide a new insight for further elucidating the specific mechanism of avian neuronal apoptosis caused by DLM.

\section{Materials And Methods}

\subsection{Animal and experimental protocol}

Forty healthy male quails (average body weight of $80 \pm 10 \mathrm{~g}, 21$ days old) were purchased from Wanjia Farm in Harbin, China. The quails were managed in the animal room of Northeast Agricultural University with the standard laboratory conditions (temperature $22 \pm 2^{\circ} \mathrm{C}$, light $12 \mathrm{~h} /$ dark $12 \mathrm{~h}$ cycle, relative humidity $55 \pm 5 \%$.). Food and water were obtained freely throughout the entire experiment (Li et al., 2021a; Lv et al., 2020).

After a week of adaptive feeding, four groups of quails were randomly assigned ( $n=10$ per group): control group (normal saline administered by gavage), low dose (15 mg/kg DLM administered by gavage), medium dose ( $30 \mathrm{mg} / \mathrm{kg}$ DLM administered by gavage), and high dose ( $45 \mathrm{mg} / \mathrm{kg} \mathrm{DLM}$ administered by gavage). Treatment duration was 12 weeks. The quails were euthanized and their cerebrum tissues were quickly dissected (Han et al., 2020b). Some fresh cerebrum tissues were used for the analysis of malondialdehyde (MDA), glutathione (GSH), and superoxide dismutase (SOD). The 
remaining cerebrum tissues were stored in $4 \%$ paraformaldehyde solution and $-80^{\circ} \mathrm{C}$ refrigerator. ( $\mathrm{Li}$ et al., 2019a). Our animal experimental procedure was authorized by the Ethical Committee for Animal Experiments (Northeast Agricultural University, Harbin, China).

\subsection{Chemicals}

DLM was purchased from Nanjing Red Sun Co., Ltd. (Nanjing, China). MDA, GSH, SOD, and ATP determination kits were provided by Nanjing Jiancheng Bioengineering Research Institute (Nanjing, China). The terminal deoxynucleotidyl transferase-mediated dUTP nick end labeling (TUNEL) assay kit was obtained from Roche (Germany). The DAB kit was purchased from Bude Biotechnology Co., Ltd (Wuhan, China). GAPDH was provided by Hangzhou Goodhere Biotechnology Co., Ltd. (Hangzhou, China). Bicinchoninic acid (BCA) protein assay kit, RIPA, and PMSF were obtained from Beyotime Institute of Biotechnology (Shanghai, China).

\subsection{Histopathological analysis}

Quail cerebrum tissues were soaked with $4 \%$ paraformaldehyde for $48 \mathrm{~h}$, embedded in paraffin and sectioned in $0.5 \mu \mathrm{m}$ thickness. Cerebrum tissue sections were fixed on glass slides, then dewaxed and stained with hematoxylin and eosin (H\&E). Finally, the sections were fixed with neutral resin. In addition, the pathological changes were observed by a light microscope (BX-FM, Olympus Corp, Tokyo, Japan) (Li et al., 2021b).

\subsection{Transmission electron microscopy}

Fresh cerebrum tissues of quails were cut into small pieces less than $1 \mathrm{~mm}^{3}$ with a sharp blade and fixed in $2.5 \%$ glutaraldehyde for $24 \mathrm{~h}$ at $4^{\circ} \mathrm{C}$ (Yang et al., 2020b). These cerebrum tissues were fixed again with $1 \%$ osmic acid and rinsed with $0.1 \mathrm{~mol} / \mathrm{L}$ phosphate-buffered saline (PBS) before and after fixation. The tissue blocks were dehydrated with different concentrations of ethanol at $4^{\circ} \mathrm{C}$. After embedding and curing, the tissue blocks were cut into ultrathin sections. Then they were dyed with uranyl acetate and lead citrate. Finally, the ultrastructure of quail cerebrum was observed by a transmission electron microscope (TEM) (Tokyo, Japan).

\subsection{Measurement of oxidative stress bio-chemical markers}

Quail cerebrum tissues were mixed with PBS buffer and homogenized on ice plate for 2 min with a portable disperser (S10, scientz, Ningbo, China). Then centrifugation was carried out at $3000 \mathrm{r} / \mathrm{min}$ for 15 min at $4^{\circ} \mathrm{C}$. After centrifugation, the supernatant was used to measure the activity of SOD, and the contents of MDA and GSH in quail cerebrum with the corresponding commercial kits (Chen et al., 2020; Yang et al., 2020d).

\subsection{Measurement of ATP concentration in cerebrum}

The ATP content in cerebrum tissue of quail was determined by phosphomolybdic acid colorimetry. The cerebrum tissue was mixed with boiling distilled water to make homogenate. After boiling and centrifugation, the supernatant was taken for testing (Li et al., 2019b). According to the manufacturter's 
instructions, we added the corresponding reagents. Finally, the absorbance was measured by spectrophotometer (PHILES, 156, Nanjing, China) with the wavelength of $636 \mathrm{~nm}$. The protein concentration of cerebrum tissue was determined by BCA method. The results of ATP content were calculated by the known formula in the instructions of ATP kit.

\subsection{TUNEL assay}

TUNEL assay was used to detect apoptosis. After the quail cerebrum was fixed by perfusion with $4 \%$ paraformaldehyde, paraffin sections were prepared routinely, and the section thickness was $4 \mu \mathrm{m}$ (Liu et al., 2018). We performed TUNEL staining according to the manufacturer's instructions. The sections were treated with $20 \mu \mathrm{g} / \mathrm{mL}$ proteinase $\mathrm{K}$ for $15 \mathrm{~min}$ at room temperature and then washed two times with PBS. After washing with PBS, the sections were treated with blocking reagent for $30 \mathrm{~min}$ at room temperature and washed with PBS for two times. Erasing the water around the samples, the slides were immersed in the TUNEL reaction mixture for $60 \mathrm{~min}$ in a dark humid environment at $37^{\circ} \mathrm{C}$. After washing slides three times with PBS and erasing the water around the slides, slides were incubated in ConverterPOD for 30 min at $37^{\circ} \mathrm{C}$, followed by PBS washing. After PBS washing, the DAB solution was used to develop the stain. The samples were incubated at room temperature for $30 \mathrm{~min}$ and washed with PBS for three times, then dehydrated, and mounted in neutral resins. Apoptotic cells were stained brown indicating positive cells, and non-apoptotic cells were stained blue indicating negative cells. The cells were examined by a light microscope. The TUNEL index (\%) was calculated by dividing the number of TUNEL positive cells by the total number of cells. This index was considered in assessing the apoptotic index of TUNEL-stained cerebrum tissues. Five regions of randomly selected TUNEL stained sections were counted for each sample and the average was calculated (Wang et al., 2021a; Zhang et al., 2017).

\subsection{Quantitative real-time PCR}

In order to extract total RNA from quail cerebrum tissue, Trizol reagent was used. RNA concentration was determined by using ultramicro nucleic acid protein analyzer (Implen, N60, Germany), then the RNA was reverse transcribed into cDNA by a cDNA reverse transcription kit (Vazyme, Nanjing). As shown in Table 1, specific primers were synthesized by Sangon Biotech (Shanghai, China). The gene was combined with the corresponding primer according to the instructions of the SYBR Green RT-qPCR Supermix kit (Vazyme, Nanjing, China). The levels of relative mRNA were analyzed by the Bio-Rad CFX96 touch (Hercules, CA, USA). $2^{-\triangle \Delta C T}$ method was used to analysis the data (Li et al., 2020a; Zhang et al., 2020a). 
Table 1

Primer sequences

\begin{tabular}{|llll|}
\hline Gene & Gene bank & Primer sequences & Product size (bp) \\
\hline AlFM & XM_032444417.1 & F: AAAGGTGGAGACCGACCACA & 143 \\
& & R: CCCAGATATTGGAGCGTGCC & \\
\hline EIF2AK3 & XM_015862788.2 & F: CGGCGGCTGGAGTTGAAGAAG & 121 \\
& & R: TCGTCCTCCACCGTCACATCTG & \\
\hline ATF6 & XM_015879449.2 & F: GATTGGACAAGAGAGAGGGTGA & 162 \\
& XM_015869467.2 & F: CGGTGCAGAATGTGCCTGAT & 139 \\
\hline IRE1 & R: CGAGAAGCGATGCCCACAAT & \\
& XM_015879544.1 & F: TGAGGGCAATGAGAAATAAGAAGC & 127 \\
\hline Cytochrome C & XM_015853794.2 & F: CGGAGGGCTTCTCTTACACA & 136 \\
& & R: TTCTTCTTGATACCCGCAAA & \\
\hline Bcl-2 & XM_015854617.2 & F: GATGACCGAGTACCTGAACC & 114 \\
& & R: CAGGAGAAATCGAACAAAGGC & \\
\hline Caspase-3 & XM_015861411.2 & F:TGGCCCTCTTGAACTGAAAG & 139 \\
& & R: TCCACTGTCTGCTTCAATACC & \\
\hline
\end{tabular}

\subsection{Western blot analysis}

Western blot analysis is a valuable study. The cerebrum tissue of quail was lysed with the lysate composed of PMSF and RIPA, and the total proteins were extracted from the cerebrum tissue, then measured by BCA kit (Wang et al., 2020). Before transferring the proteins to PVDF membranes, the proteins should be electrophoresed in $12 \%$ gel SDS-PAGE. The membranes were then sealed in the blocking solution for $2 \mathrm{~h}$, followed by overnight incubation at $4^{\circ} \mathrm{C}$ with the original antibody (Zheng et al., 2020). Next, TBST was used to wash the membranes, and the membranes were incubated with the appropriate secondary antibody for $40 \mathrm{~min}$ at $37^{\circ} \mathrm{C}$. Finally, the membranes were washed with TBST again, the protein band strength was quantified by Image Pro-Plus 6.0 software (Rockville, MD, USA) (Han et al., 2019).

\subsection{Protein-protein interaction analysis}

In order to explore the relationship between target genes, Protein-protein interaction (PPI) network was constructed. Since the database of STRING (http://string-db.org/, Version 11.0) does not contain quail, 
we refer to the more popular model species of "Mus musculus". Specifically, we chosed "Mus musculus" as the organism, and input inputted the target genes such as PERK (Eif2ak3), ATF6 (Atf6), IRE1 (Ern1), GRP78 (Hspa5), AlF (Aifm1), Cyt C (Cycs), caspase-3 (Casp3), and Bcl-2 (Bcl2) into the STRING database. And then constructed PPI network of the selected species with the genes that can be retrieved from the database (Li et al., 2021c; Yang et al., 2021).

\subsection{Statistical analysis}

SPSS 19.0 software (SPSS, Chicago, IL, USA) was used to analyze data. The data were presented as mean \pm SEM. One-way ANOVA was performed to compare multiple groups following Tukey's post-hoc test. $P<0.05$ was considered statistically significant.

\section{Results}

\subsection{DLM treatment exacerbated cerebrum injury in quail}

As shown in Fig. 1, the cerebrum tissue structure of the control group was normal, with normal neuronal morphology and diversity. Compared with the control group, the neuronal morphology was changed and some neurons were shrunk in the DLM groups. In addition, some nuclei were disappeared and a large number of diseased neurons were appeared in the high dose DLM group.

\subsection{DLM treatment changed neurons ultrastructure in quail cerebrum}

To determine the damage of neurons, we used TEM to observe the ultrastructure of quail cerebrum neurons. The normal morphology of nucleus, mitochondria, and ER could be observed in the control group. However, changes in nuclear morphology, mitochondrial swelling, and ER swelling were observed in DLM-treatment groups. In addition, the happening of nuclear lysis, mitochondrial swelling and ridge rupture, and ER swelling occurred significantly in the high dose group compared with the control group (Fig. 2).

\subsection{DLM treatment induced oxidative stress and reduced ATP level in quail cerebrum}

To analyze the level of oxidative stress in the cerebrum tissues of quails, we detected the concentration of MDA and GSH, and the activity of SOD. As expected, DLM significantly increased the concentration of MDA (Fig. 3A). In addition, treatment with DLM significantly decreased GSH concentration and SOD activity compared with the control group (Fig. 3B and C). The ATP concentration of quail cerebrum was shown in Fig. 3D. Compared with the control group, the ATP concentration of quail cerebrum in DLMtreatment groups decreased significantly and this effect was dose-related. 


\subsection{DLM treatment induced neuronal apoptosis in quail cerebrum}

Apoptosis of cerebrum neurons in quail was determined by TUNEL staining. There were only a few TUNEL-positive cells in the control group. However, the number of apoptotic cells increased significantly in DLM-treatment groups and it was a dose-dependent relationship. Furthermore, the apoptosis rate of neurons in high dose DLM group was the highest (Fig. 4).

\subsection{DLM induced apoptosis via activating the ER pathway and exacerbating the mitochondrial damage pathway in quail cerebrum}

The ER pathway and mitochondrial pathway are important pathways for studying neuronal apoptosis. We measured the ER stress related mRNA expression levels of glucose regulated protein $78 \mathrm{kD}$ (GRP78), ATF6, PERK, and IRE1. The results showed that the expressions of GRP78, ATF6, PERK, and IRE1 in DLM groups were increased significantly compared to the control group and showed a dose-dependent relationship (Fig. 5D). In the mitochondrial apoptotic pathway, we detected the protein expressions of Bcl2 and caspase-3. Furthermore, we measured the mRNA expression levels of AIF, Cyt C, Bcl-2, and caspase3. In DLM groups, the protein expression levels of Bcl-2 (Fig. 5A) was decreased significantly and the protein expression levels of caspase-3 (Fig. 5B) was increased significantly in a dose-dependent manner. As shown in Fig. 4C, the mRNA expression levels of AIF, Cyt C, and caspase-3 were increased significantly and the mRNA expression levels of Bcl-2 decreased in DLM groups, and this effect was dose-related.

\subsection{PPI analysis}

We constructed a PPI analysis network of cerebrum damage using the STRING 10 database (Fig. 6) to confirm our conclusion. The cerebrum damage dynamic clusters included PERK, ATF6, IRE1, GRP78, AIF, Cyt C, caspase-3, and Bcl-2. The PPI analysis revealed the relationship between cerebrum damage and ER stress, as well as mitochondrial dysfunction.

\section{Discussion}

Apoptosis is a process of cells organizing self-destruction (Chen et al., 2007). Numerous studies have demonstrated that DLM can cause neuronal apoptosis (Huang et al., 2019; Liu et al., 2018; Strungaru et al., 2019). In this study, we explored the relationship among quail cerebrum neuronal apoptosis, mitochondrial, and ER. The mitochondrial apoptosis pathway is regulated by the members of the Bcl-2 family including pro-apoptotic (Bax) and anti-apoptotic ( $\mathrm{Bcl}-2, \mathrm{Bcl}-\mathrm{XL})$ proteins, while ER apoptosis pathway is activated by long-term or serious ER stress (Li et al., 2017; Logue et al., 2013). Here, we found that DLM decreased Bcl-2 protein expression, suggesting that DLM promotes neuronal apoptosis of quail cerebrum related with mitochondrial. Indeed, this was confirmed by TUNEL staining of cerebrum tissue from quail. Thus, DLM exposure induces neuronal apoptosis in quail cerebrum. 
ER stress pathway is a new type of apoptosis pathway (Yang et al., 2020). Exposed to DLM, neurons may undergo ER stress (Hossain et al., 2020). Severe or long-term ER stress impairs ER function, and then apoptosis will be induced by activating ER stress-mediated apoptosis signaling pathway (Xu et al., 2020). At this time, the three activated transmembrane proteins ATF-6, IRE, and PERK will promote the production of C/EBP-homologous protein (CHOP), and then trigger apoptosis. Normally, the three membrane proteins are combined with chaperone GRP78/Bip and keep inactive. However, when ER stress outbreak, ATF-6, IRE, and PERK will be separated from GRP78/Bip and be activated. IRE1 and ATF-6 are transfered into the nucleus and bind to the ER stress response element to initiate the transcription and expression of CHOP. The transcription factor ATF-4 which is the downstream of PERK can bind to the AARE domain of the CHOP and promote CHOP expression, then down-regulate the expression of antiapoptotic protein Bcl-2 (Rauti et al., 2020; Wang et al., 2021b). In our experiment, the findings indicated that DLM exposure obviously induced ER stress and further triggered neuronal apoptosis in quail cerebrum. Therefore, ER stress gets involved in the progress of DLM-induced apoptosis of quail cerebrum and plays an important role.

Mitochondria is the main source of ROS (Patel et al., 2020). The destruction of mitochondria will lead to the accumulation of a large number of ROS, which causes more serious mitochondrial dysfunction (Awoyemi et al., 2020; Han et al., 2021). MDA, SOD, and GSH are important indicators for detecting oxidative stress (Abdel-Daim et al., 2020). The release of ROS can cause oxidative stress in cells and it can trigger apoptosis through a variety of signaling pathways. When mitochondria undergo apoptosis, the expression of Bcl-2 will be inhibited (Zhang et al., 2020b). Simultaneously, the permeability of the mitochondrial membrane changes, then AIF and Cyt $C$ are released from the mitochondria into the cytoplasm. AIF can be transported into the nucleus and cause DNA fragmentation (Li et al., 2020b). AIF and Cyt $\mathrm{C}$ are both pro-apoptotic factors (Han et al., 2018). These factors activate the caspase signaling pathway and undergo a series of enzyme-linked reactions to apoptosis. Our results showed that DLM induced mitochondrial damage of quail cerebrum neurons, causing oxidative stress of neurons. Meanwhile, the expressions of mitochondrial apoptosis-related factors AIF and Cyt C were increased. The TEM and the ATP assay results further confirmed DLM-induced mitochondria dysfunction in quail cerebrum. Hence, mitochondria dysfunction is involved in the process of neuronal apoptosis in quail cerebrum induced by chronic DLM exposure.

The use of pesticides is closely related to human health (Oudejans et al., 2020). DLM is a highly effective insecticide, but with a defect of polluting the environment. As a representative animal of poultry, quail has excellent advantages of high sensitivity, easy to feed, and small size. Besides, the toxic effects of quails are closer to the toxic effects of toxic substances in the natural environment, because of their idiographic genetic conditions. Therefore, quail has high great research value in pesticide safety evaluation (Bean et al., 2019). Studies on the effects of DLM neurotoxic have been reported in mammals, fish, and insects, but no reports have been reported on birds. According to report, in mouse cells, DLM can continuously increase the content of $\mathrm{Ca}^{2+}$ in cells, and the imbalance of $\mathrm{Ca}^{2+}$ homeostasis will promote ER stress (Choi et al., 2007). The response of ER stress will produce a large amount of CHOP, which inhibits the 
expression of Bcl-2 located on the mitochondrial membrane, thereby promoting apoptosis of the mitochondrial pathway (Wu et al., 2007). With the gradual loss of ER function, ER will further release $\mathrm{Ca}^{2+}$ into the cell cytoplasm (McFarland et al., 2020). High concentrations of $\mathrm{Ca}^{2+}$ can directly act on mitochondria, causing mitochondrial dysfunction and triggering mitochondrial-related apoptosis (Quintana et al., 2020). However, the effect of DLM on intracellular $\mathrm{Ca}^{2+}$ in cells of quail has not been reported to date. The specific mechanism of ER induced by DLM in quails is still unclear. In our study, the results suggest that DLM caused neuronal apoptosis of quail cerebrum. However, the mechanism is still unclear whether neuronal apoptosis of quail is caused by ER stress and mitochondrial dysfunction working together or separately (Fig. 7). Hence, we speculate that DLM induces neurotoxicity in quail cerebrum neurons, which is similar to DLM-induced cytotoxicity by increasing intracellular $\mathrm{Ca}^{2+}$ concentration in other animals.

\section{Conclusion}

In conclusion, DLM exposure induces apoptosis of cerebrum neurons in quails via promoting ER stress and mitochondrial dysfunction. Our study provides a novel explanation for DLM-induced apoptosis of avian cerebrum neurons.

\section{Declarations}

\section{Availability of data and materials}

The datasets during the current study are available from the corresponding author on reasonable request.

\section{Acknowledgements}

This study was supported by the National Natural Science Foundation of China (31972754).

\section{Contributions}

Contribution of each co-author is described below:

Pengfei Wu performed the conceptualization, methodology, investigation and writing original draft.

Bing Han performed the methodology and investigation.

Qingyue Yang performed the visualization and software.

Siyu Li performed the methodology and visualization.

Xiaoqiao Wang performed the investigation and methodology. 
Jiayi Li performed the investigation and formal analysis.

Ning Deng performed the investigation and formal analysis.

Biqi Han performed the investigation and software.

Yuge Liao performed the data curation and investigation.

Zhigang Zhang performed the Conceptualization, methodology, writing-review \& editing and funding acquisition.

\section{Ethics approval and consent to participate}

Our animal experimental procedure was authorized by the Ethical Committee for Animal Experiments (Northeast Agricultural University, Harbin, China). Consent to participate is not applicable.

\section{Consent for publication}

Not applicable.

\section{Conflict of interest}

There are no conflicts of interest to declare.

\section{References}

1. Abdel-Daim MM, Khalil SR, Awad A, AbuZeid, EH, El-Aziz RA, El-Serehy HA (2020) Moringa oleifera ethanolic extract of leaves influences NF-KB signaling pathway to restore kidney tissue from cobaltmediated oxidative injury and inflammation in rats. Nutrients

12:1031.https://doi.org/10.3390/nu12041031

2. Arslan H, Altun S, Özdemir S (2017) Acute toxi cation of deltamethrin results in activation of iNOS, 8OHdG and up-regulation of caspase 3 , iNOS gene expression in common carp (Cyprinus carpio L.). Aquat. Toxicol 187:90-99. https://doi.org/10.1016/j.aquatox.2017.03.014

3. Awoyemi OM, Kumar N, Schmitt C, Subbiah S, Crago J (2019) Behavioral, molecular and physiological responses of embryo-larval zebrafish exposed to types I and II pyrethroids. Chemosphere 219:526-537. https://doi.org/10.1016/j.chemosphere.2018.12.026

4. Bean TG, Gross MS , Karouna-Renier NK., Henry PFP, Schultz SL, Hladik ML, Kuivila KM, Rattner BA (2019) Toxicokinetics of Imidacloprid-Coated wheat seeds in japanese quail (Coturnix japonica) and an evaluation of hazard. Environ Sci Technol 53:3888-

3897.https://doi.org/10.1021/acs.est.8b07062

5. Chen D, Huang XW, Liu LL, Shi N (2007) Deltamethrin induces mitochondrial membrane permeability and altered expression of cytochrome $\mathrm{C}$ in rat brain. J Appl Toxicol 27:368-372. https://doi.org/10.1002/jat.1215 
6. Chen D, Kannan K, Tan HL, Zheng ZG, Feng YL, Wu Y, Widelka M (2016) Bisphenol analogues other than BPA: environmental occurrence, human exposureand Toxicity: A review. Environ Sci Technol 50:5438-5453. https://doi.org/10.1021/acs.est.5b05387

7. Chen S, Li DC, Wu XN, Chen LP, Zhang B, Tan YF, Yu DK, Niu Y, Duan HW, Li Q, Chen R, Aschner M, Zheng YX, Chen W (2020) Application of cell based biological bioassays for health risk assessment of PM2.5 exposure in three megacities, China. Environ Int 139:105703.

http://doi.org/10.1016/j.envint.2020.105703

8. Choi SE, Kim HE, Shin HC, Jang HJ, Lee KW, Kim Y, Kang SS, Chun J, Kang Y, (2007) Involvement of $\mathrm{Ca}^{2+}$-mediated apoptotic signals in palmitate-induced MIN6N8A beta cell death. Mol Cell Endocrinol 272:50-62. https://doi.org/10.1016/j.mce.2007.04.004

9. de Alvarenga ES, Carneiro VM, Resende GC, Picanço MC, Farias Ede S, Lopes MC (2012) Synthesis and insecticidal activity of an oxabicyclolactone and novel pyrethroids. Molecules 17:13989-14001. https://doi.org/10.3390/molecules171213989

10. Delpuech JM, Delahaye M (2013) The sublethal effects of deltamethrin on Trichogramma behaviors during the exploitation of host patches. Sci Total Environ 447:274-279. https://doi.org/10.1016/j.scitotenv.2012.12.096

11. Gutiérrez Y, Santos HP, Serrão JE, Oliveira EE, (2016) Deltamethrin-mediated toxicity and cytomorphological changes in the midgut and nervous system of the mayfly callibaetis radiatus. PLoS One 11:e0152383. https://doi.org/10.1371/journal.pone.0152383

12. Han B, Lv ZJ, Zhang XY, Lv YY, Li SY, Wu PF, Yang QY, Li JY, Qu B, Zhang ZG, (2020b) Deltamethrin induces liver fibrosis in quails via activation of the TGF- $\beta 1 / \mathrm{Smad}$ signaling pathway. Environ Pollut 259:113870. https://doi.org/10.1016/j.envpol.2019.113870

13. Han B, Li SY, Lv YY, Yang DQ, Li JY, Yang QY, Wu PF, Lv ZJ, Zhang ZG (2019) Dietary melatonin attenuates chromium-induced lung injury via activating the Sirt1/Pgc-1a/Nrf2 pathway. Food Funct 10:5555-5565. https://doi.org/10.1039/c9fo01152h

14. Han BQ, Lv ZJ, Han XM, Li SY, Han B, Yang QY, Wang XQ, Wu PF, Li JY, Deng N, Zhang ZG (2021) Harmful Effects of Inorganic Mercury Exposure on Kidney Cells: Mitochondrial Dynamics Disorder and Excessive Oxidative Stress. Biol Trace Elem Res. https://doi:10.1007/s12011-021-02766-3

15. Han X, Liu C, Zhang K, Guo M, Shen Z, Liu Y, Zuo Z, Cao M, Li Y (2018) Calpain and JNK pathways participate in isoflurane-induced nucleus translocation of apoptosis-inducing factor in the brain of neonatal rats. Toxicol Lett 285:60-73. https://doi.org/10.1016/j.toxlet.2017.12.022

16. Han YB, Tian M, Wang XX, Fan DH, Li WZ, Wu F, Liu L (2020a) Berberine ameliorates obesity-induced chronic inflammation through suppression of ER stress and promotion of macrophage M2 polarization at least partly via downregulating IncRNA Gomafu. Int Immunopharmacol 86:106741. https://doi.org/10.1016/j.intimp.2020.106741

17. Hossain MM, Richardson JR (2011) Mechanism of pyrethroid pesticide-induced apoptosis: Role of calpain and the ER stress pathway. Toxicol Sci 122:512-525. https://doi.org/10.1093/toxsci/kfr111 
18. Hossain MM, Richardson JR (2020) Nerve growth factor protects against pyrethroid-induced Endoplasmic Reticulum (ER) stress in primary hippocampal neurons. Toxicol Sci 174:147-158. https://doi.org/10.1093/toxsci/kfz239

19. Huang X, Liang Y, Qing Y, Chen D, Shi N (2019) Proteasome inhibition by MG-132 protects against deltamethrin-induced apoptosis in rat hippocampus. Life Sci 220:76-83. https://doi.org/10.1016/j.Ifs.2019.01.041

20. Jiang Q, Jiang ZY, Ao SQ, Gao XJ, Zhu XH, Zhang ZR, Zhang XJ (2021) Multi-biomarker assessment in the giant freshwater prawn Macrobrachium rosenbergii after deltamethrin exposure. Ecotoxicol Environ Saf 214:112067. https://doi.org/10.1016/j.ecoenv.2021.112067

21. Khalatbary AR, Ghaffari E, Mohammadnegad B (2015) Protective role of oleuropein against acute deltamethrin-induced neurotoxicity in rat brain. Iran Biomed J 19:247-253. https://doi.org/10.7508/ibj.2015.04.009

22. Li C, Zhang RX, Wei HD, Wang YA, Chen YJ, Zhang HY, Li X, Liu HG, Li JH, Bao J (2021a) Enriched environment housing improved the laying hen's resistance to transport stress via modulating the heat shock protective response and inflammation. Poult Sci 100:100939. https://doi.org/10.1016/j.psj.2020.12.036

23. Li DC, Chen S, Li Q, Chen LQ, Zhang HY, Li HY, Yu DK, Zhang R, Niu YJ, Lu SY, Ye LZ, Zeng XW, Dong GH, Chen R, Aschner M, Zheng YX, Chen W (2020a) Caloric restriction attenuates C57BL/6 J mouse lung injury and extrapulmonary toxicity induced by real ambient particulate matter exposure. Part Fibre Toxicol 17:22. https://doi.org/10.1186/s12989-020-00354-2

24. Li JY, Jiang HJ, Wu PF, Li SY, Han B, Yang QY, Wang XQ, Han BQ, Deng N, Qu B, Zhang ZG (2021c) Toxicological effects of deltamethrin on quail cerebrum: Weakened antioxidant defense and enhanced apoptosis. Environ Pollut 286:117319. https://doi:10.1016/j.envpol.2021.117319

25. Li JY, Zheng XY, Ma XY, Xu XY, Du Y, Lv QJ, Li XR, Wu Y, Sun HX, Yu LJ, Zhang ZG (2019a) Melatonin protects against chromium ( $\mathrm{VI}$ )-induced cardiac injury via activating the AMPK/Nrf2 pathway. $\mathrm{J}$ Inorg Biochem 197:110698. https://doi.org/10.1016/j.jinorgbio.2019.110698

26. Li PA, Hou X, Hao S (2017) Mitochondrial biogenesis in neurodegeneration. J Neurosci Res 95:20252029. https://doi.org/10.1002/jnr.24042

27. Li SY, Baiyun RQ, Lv ZJ, Li JY, Han DX, Zhao WY, Yu LJ, Deng N, Liu ZY, Zhang ZG (2019b) Exploring the kidney hazard of exposure to mercuric chloride in mice: Disorder of mitochondrial dynamics induces oxidative stress and results in apoptosis. Chemosphere 234:822-829. https://doi.org/10.1016/j.chemosphere.2019.06.096

28. Li SY, Zheng XY, Zhang XY, Yu HX, Han B, Lv YY, Liu Y, Wang XQ, Zhang ZG (2021b) Exploring the liver fibrosis induced by deltamethrin exposure in quails and elucidating the protective mechanism of resveratrol. Ecotoxicol Environ Saf 207:111501. https://doi.org/10.1016/j.ecoenv.2020.111501

29. Li Y, Ding HY, Liu LH, Song YX, Du XL, Feng SB, Wang XC, Li XB, Wang Z, Li XW, Li JC, Wu JJ, Liu GW (2020b) Non-esterified fatty acid induce dairy cow hepatocytes apoptosis via the mitochondria- 
mediated ROS-JNK/ERK signaling pathway. Front Cell Dev Biol 8:245.

https://doi.org/10.3389/fcell.2020.00462

30. Liu BY, Yu HX, Baiyun RQ, Lu JJ, Li SY, Bing QZ, Zhang XY, Zhang ZG (2018a) Protective effects of dietary luteolin against mercuric chloride-induced lung injury in mice: Involvement of AKT/Nrf2 and NF-kB pathways. Food Chem Toxicol 113:296-302. https://doi.org/10.1016/j.fct.2018.02.003

31. Liu XY, Zhang QP, Li SB, Mi P, Chen DY, Zhao X, Feng XZ (2018b) Developmental toxicity and neurotoxicity of synthetic organic insecticides in zebrafish (Danio rerio): A comparative study of deltamethrin, acephate, and thiamethoxam. Chemosphere 199:16-25.

https://doi.org/10.1016/j.chemosphere.2018.01.176

32. Logue SE, Cleary P, Saveljeva S, Samali A (2013) New directions in ER stress-induced cell death. Apoptosis 18:537-546. https://doi.org/10.1007/s10495-013-0818-6

33. Lv YY, Bing QZ, Lv ZJ, Xue JD, Li SY, Han B, Yang QY, Wang XQ, Zhang ZG (2020) Imidaclopridinduced liver fibrosis in quails via activation of the TGF- $\beta 1 /$ Smad pathway. Sci Total Environ 705:135915. https://doi.org/10.1016/j.scitotenv.2019.135915

34. Ma B, Zhang H, Wang Y, Zhao A, Zhu ZM, Bao XW, Sun Y, Li L, Zhang Q (2018) Corosolic acid, a natural triterpenoid, induces ER stress-dependent apoptosis in human castration resistant prostate cancer cells via activation of IRE-1/JNK, PERK/CHOP and TRIB3. J Exp Clin Cancer Res 37:210. https://doi.org/10.1186/s13046-018-0889-x

35. Mehlhorn H, Schumacher B, Jatzlau A, Abdel-Ghaffar F, Al-Rasheid KA, Klimpel S, Pohle H (2017) Efficacy of deltamethrin (Butox ${ }^{\circledR} 7.5$ pour on) against nymphs and adults of ticks (Ixodes ricinus, Rhipicephalus sanguineus) in treated hair of cattle and sheep. Parasitol Res 108:963-971. https://doi.org/10.1007/s00436-010-2141-2

36. McFarland SJ, Weber DS, Choi CS, Lin MT, Taylor MS (2020) Ablation of endothelial TRPV4 channels alters the dynamic Ca signaling profile in mouse carotid arteries. Int J Mol Sci 21:2179. https://doi.org/10.3390/ijms21062179

37. Miranda-Silva D, Wüst RCl, Conceição G, Gonçalves-Rodrigues P, Gonçalves N, Gonçalves A, Kuster DWD, Leite-Moreira AF, Velden JV, de Sousa Beleza Jorge M, Magalhães J, Stienen Ger JM, FalcãoPires I (2020) Disturbed cardiac mitochondrial and cytosolic calcium handling in a metabolic riskrelated rat model of heart failure with preserved ejection fraction. Acta Physiol 228:13378. https://doi.org/10.1111/apha.13378

38. Ogaly HA, Khalaf AA, Ibrahim MA, Galal MK, Abd-Elsalam RM (2015) Influence of green tea extract on oxidative damage and apoptosis induced by deltamethrin in rat brain. Neurotoxicol Teratol 50:23-31. https://doi.org/10.1016/j.ntt.2015.05.005

39. Oudejans L, Mysz A, Gibb Snyder E, Wyrzykowska-Ceradini B, Nardin J, Tabor D, Starr J, Stout D, Lemieux P (2020) Remediating indoor pesticide contamination from improper pest control treatments: Persistence and decontamination studies. J Hazard Mater 397:122743. https://doi.org/10.1016/j.jhazmat.2020.122743 
40. Patel J, Baptiste BA, Kim E, Hussain M, Croteau DL, Bohr VA (2020) DNA damage and mitochondria in cancer and aging. Carcinogenesis 41:1625-1634. https://doi.org/10.1093/carcin/bgaa114

41. Pluquet $O$, Abbadie C (2021) Cellular senescence and tumor promotion: Role of the unfolded protein response. Adv Cancer Res 150:285-334. https://doi.org/10.1016/bs.acr.2021.01.001

42. Quindroit P, Crépet A, Brochot C (2021) Estimating human exposure to pyrethroids' mixtures from biomonitoring data using physiologically based pharmacokinetic modeling. Environ Res 192:110281. https://doi.org/10.1016/j.envres.2020.110281

43. Quintana DD, Garcia JA, Anantula Y, Rellick SL, Engler-Chiurazzi EB, Sarkar SN, Brown CM, Simpkins JW (2020) Amyloid- $\beta$ causes mitochondrial dysfunction via a $\mathrm{Ca}^{2+}$-Driven upregulation of oxidative phosphorylation and superoxide production in cerebrovascular endothelial cells. J Alzheimers Dis 75:119-138. https://doi.org/10.3233/JAD-190964

44. Rauti R, Qaisiya M, Tiribelli C, Ballerini L, Bellarosa C (2020) Bilirubin disrupts calcium homeostasis in neonatal hippocampal neurons: A new pathway of neurotoxicity. Arch Toxicol 94:845-855. https://doi.org/10.1007/s00204-020-02659-9

45. Saoudi M, Badraoui R, Bouhajja H, Ncir M, Rahmouni F, Grati M, Jamoussi K, Feki AE (2017) Deltamethrin induced oxidative stress in kidney and brain of rats: Protective effect of Artemisia campestris essential oil. Biomed Pharmacother 94:955-963. https://doi.org/10.1016/j.biopha.2017.08.030

46. Smith GM, Gallo G (2018) The role of mitochondria in axon development and regeneration. Dev Neurobiol 78:221-237. https://doi.org/10.1002/dneu.22546 So, J.S., 2019. Erratum to: Roles of endoplasmic reticulum stress in immune responses. Mol. Cells 42, 501. https://doi.org/10.14348/molcells.2019.1241

47. Strungaru SA, Plavan G, Ciobica A, Nicoara M, Robea MA, Solcan C, Petrovici A (2019) Toxicity and chronic effects of deltamethrin exposure on zebrafish (Danio rerio) as a reference model for freshwater fish community. Ecotoxicol Environ Saf 171:854-862. https://doi.org/10.1016/j.ecoenv.2019.01.057

48. Sun WQ, Ni ZJ, Li R, Chang XL, Li WH, Yang MJ, Zhou ZJ (2021) Flurochloridone induces Sertoli cell apoptosis through ROS-dependent mitochondrial pathway. Ecotoxicol Environ Saf 216:112183. https://doi.org/10.1016/j.ecoenv.2021.112183

49. Wang XQ, Han B, Wu PF, Li SY, Lv YY, Lu JJ, Yang QY, Li JY, Zhu Y, Zhang ZG (2020) Dibutyl phthalate induces allergic airway inflammation in rats via inhibition of the Nrf2/TSLP/JAK1 pathway. Environ Pollut 267:115564. https://doi.org/10.1016/j.envpol.2020.115564

50. Wang XQ, Lv ZJ, Han B, Li SY, Yang QY, Wu PF, Li JY, Han BQ, Deng N, Zhang ZG (2021a) The aggravation of allergic airway inflammation with dibutyl phthalate involved in Nrf2-mediated activation of the mast cells. Sci Total Environ 789:148029. https://doi:10.1016/j.scitotenv.2021.148029

51. Wang XY, Zhuang Y, Fang YK, Cao HB, Zhang CY, Xing CH, Guo XQ, Li GY, Liu P, Hu GL, Yang F (2021b) Endoplasmic reticulum stress aggravates copper-induced apoptosis via the 
PERK/ATF4/CHOP signaling pathway in duck renal tubular epithelial cells. Environ Pollut 272:115981. https://doi.org/10.1016/j.envpol.2020.115981

52. Wu MZ, Fu T, Chen JX, Lin YY, Yang JE, Zhuang SM (2020) LncRNA GOLGA2P10 is induced by PERK/ATF4/CHOP signaling and protects tumor cells from ER stress-induced apoptosis by regulating Bcl-2 family members. Cell Death Dis 11:276. https://doi.org/10.1038/s41419-020-2469-1

53. Xu LL, Xu Q, Xu F, Zhang WX, Chen Q, Wu H, Chen XZ (2020) MicroRNA-325-3p prevents sevofluraneinduced learning and memory impairment by inhibiting Nupr1 and C/EBP $\beta /$ IGFBP5 signaling in rats. Aging (Albany NY) 12:5209-5220. https://doi.org/10.18632/aging.102942

54. Yang DQ, Han B, Baiyun RQ, Lv ZJ, Wang XQ, Li SY, Lv YY, Xue JD, Liu Y, Zhang ZG (2020d) Sulforaphane attenuates hexavalent chromium-induced cardiotoxicity via the activation of the Sesn2/AMPK/Nrf2 signaling pathway. Metallomics 12:2009-2020. https://doi.org/10.1039/d0mt00124d

55. Yang DQ, Yang QY, Fu N, Li SY, Han B, Liu Y, Tang YQ, Guo XY, Lv Z, Zhang ZG (2020c) Hexavalent chromium induced heart dysfunction via Sesn2-mediated impairment of mitochondrial function and energy supply. Chemosphere 264:128547. https://doi.org/10.1016/j.chemosphere.2020.128547

56. Yang LH, Guo NN, Fan W, Ni CM, Huang MB, Bai LP, Zhang L, Zhang XW, Wen YB, Li Y, Zhou XS, Bai J (2020b) Thioredoxin-1 blocks methamphetamine-induced injury in brain through inhibiting endoplasmic reticulum and mitochondria-mediated apoptosis in mice. Neurotoxicology 78:163-169. https://doi.org/10.1016/j.neuro.2020.03.006

57. Yang QY, Han B, Li SY, Wang XQ, Wu PF, Liu Y, Li JY, Han BQ, Deng N, Zhang ZG (2021) The link between deacetylation and hepatotoxicity induced by exposure to hexavalent chromium. J Adv Res. http://doi.org/10.1016/j.jare.2021.04.002

58. Yang QY, Han B, Xue JD, Lv YY, Li SY, Liu Y, Wu PF, Wang XQ, Zhang ZG (2020a) Hexavalent chromium induces mitochondrial dynamics disorder in rat liver by inhibiting AMPK/PGC-1a signaling pathway. Environ Pollut 265:114855. https://doi.org/10.1016/j.envpol.2020.114855

59. Yilmaz E (2017) Endoplasmic reticulum stress and obesity. Adv Exp Med Biol 960:261-276. https://doi.org/10.1007/978-3-319-48382-5-11

60. Zhang HL, Tan X, Yang DQ, Lu JJ, Liu BY, Baiyun RQ, Zhang ZG (2017) Dietary luteolin attenuates chronic liver injury induced by mercuric chloride via the Nrf2/NF-KB/P53 signaling pathway in rats. Oncotarget 8:40982-40993. https://doi.org/10.18632/oncotarget.17334

61. Zhang LL, Huang XL, Guo T, Wang HX, Fan HY, Fang L (2020b) Study of cinobufagin as a promising anticancer agent in uveal melanoma through intrinsic apoptosis pathway. Front Oncol 10:325. https://doi.org/10.3389/fonc.2020.00325

62. Zhang ZG, Guo CM, Jiang HJ, Han B, Wang XQ, Li SY, Lv YY, Lv ZJ, Zhu Y (2020a) Inflammation response after the cessation of chronic arsenic exposure and post-treatment of natural astaxanthin in liver: Potential role of cytokine-mediated cell-cell interactions. Food Funct 11:9252-9262. https://doi.org/10.1039/d0fo01223h 
63. Zheng XY, Li SY, Li JY, Lv YY, Wang XQ, Wu PF, Yang QY, Tang YQ, Liu Y, Zhang ZG (2020) Hexavalent chromium induces renal apoptosis and autophagy via disordering the balance of mitochondrial dynamics in rats. Ecotoxicol Environ Saf 204:111061. https://doi.org/10.1016/j.ecoenv.2020.111061

64. Zhong JK, Ouyang HC, Zheng SL, Guo ZZ, Chen YY, Zhong YL, Zhong WH, Zuo LE, Lu JH (2020) The YAP/SERCA2a signaling pathway protects cardiomyocytes against reperfusion-induced apoptosis. Aging (Albany NY) 12:13618-13632. https://doi.org/10.18632/aging.103481

65. Zhou BH, Wei SS, Jia LS, Zhang Y, Miao CY, Wang HW (2020) Drp1/Mff signaling pathway is involved in fluoride-induced abnormal fission of hepatocyte mitochondria in mice. Sci Total Environ 25:138192. https://doi.org/10.1016/j.scitotenv.2020.138192

\section{Figures}

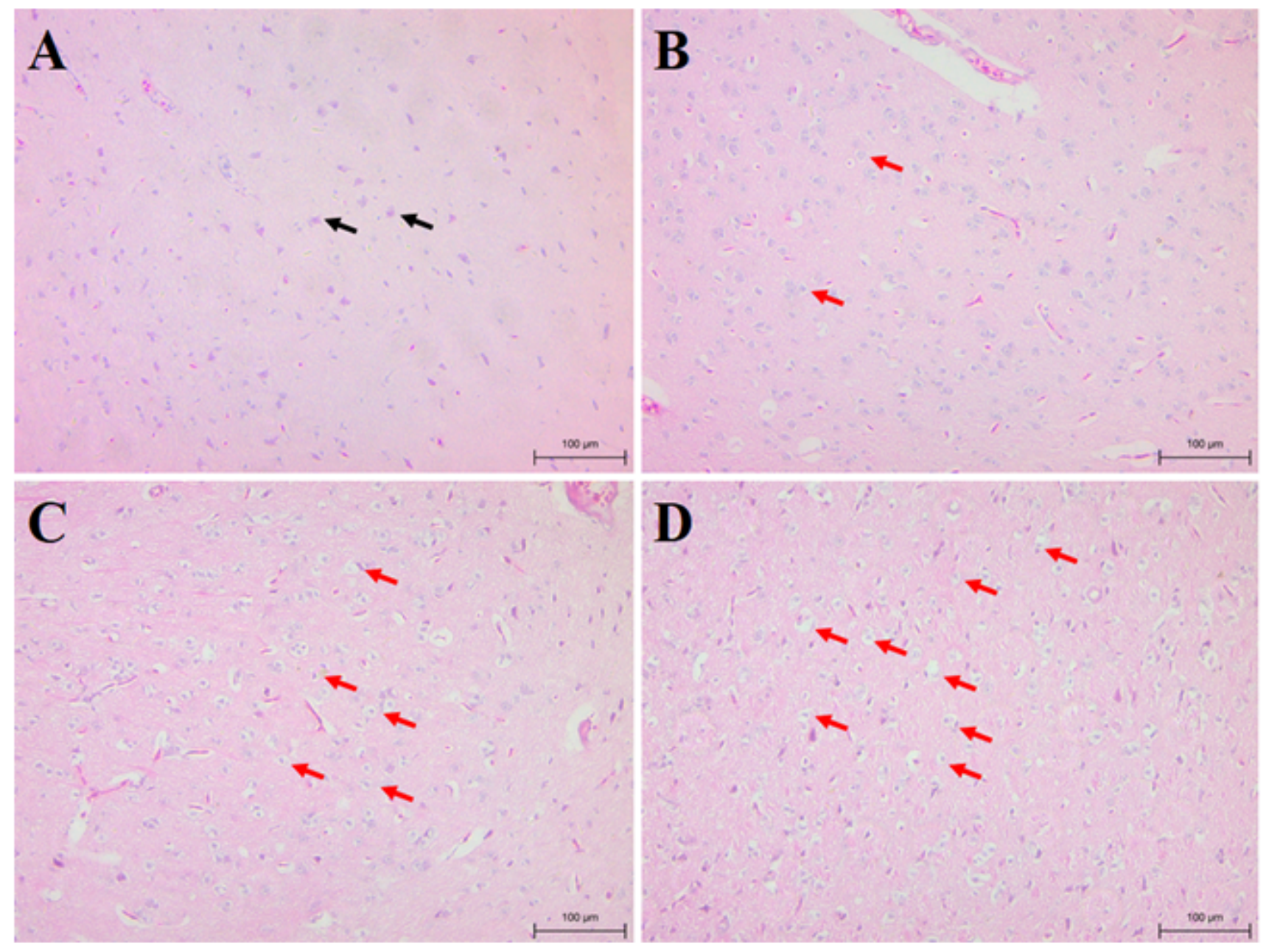

\section{Figure 1}

Effect of exposure to DLM on quail cerebrum injury. (A) Control group. Normal structure. (B) $15 \mathrm{mg} / \mathrm{kg}$ DLM group. Significant swelling of neurons. (C) $30 \mathrm{mg} / \mathrm{kg}$ DLM group. Neurons shrink significantly. (D) $45 \mathrm{mg} / \mathrm{kg}$ DLM group. Neurons shrink and disappear. The black arrows indicate the normal neurons, the red arrows indicate the shrunken neurons. (H\&E staining, $200 \times$ magnification). 

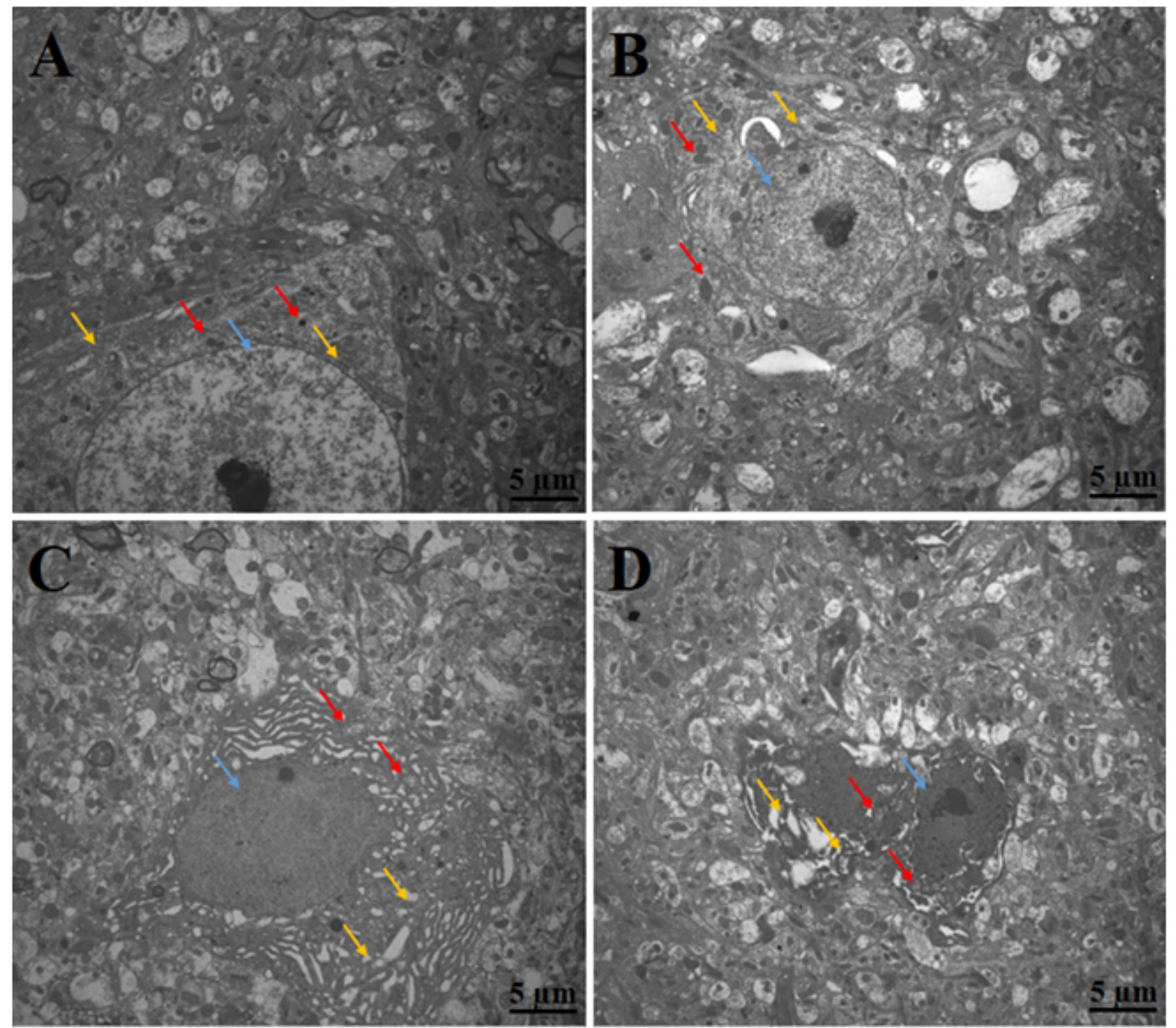

\section{Figure 2}

The ultrastructure of quail cerebrum tested by transmission electron microscopy. (A) Control group. (B) 15 $\mathrm{mg} / \mathrm{kg}$ DLM group. (C) $30 \mathrm{mg} / \mathrm{kg}$ DLM group. (D) $45 \mathrm{mg} / \mathrm{kg}$ DLM group. The yellow arrows indicate the endoplasmic reticulum, the red arrows indicate the mitochondria, the blue arrows indicate the nucleus. (Scale bar $=5 \mu \mathrm{m}, 20000 \times$ magnification). 


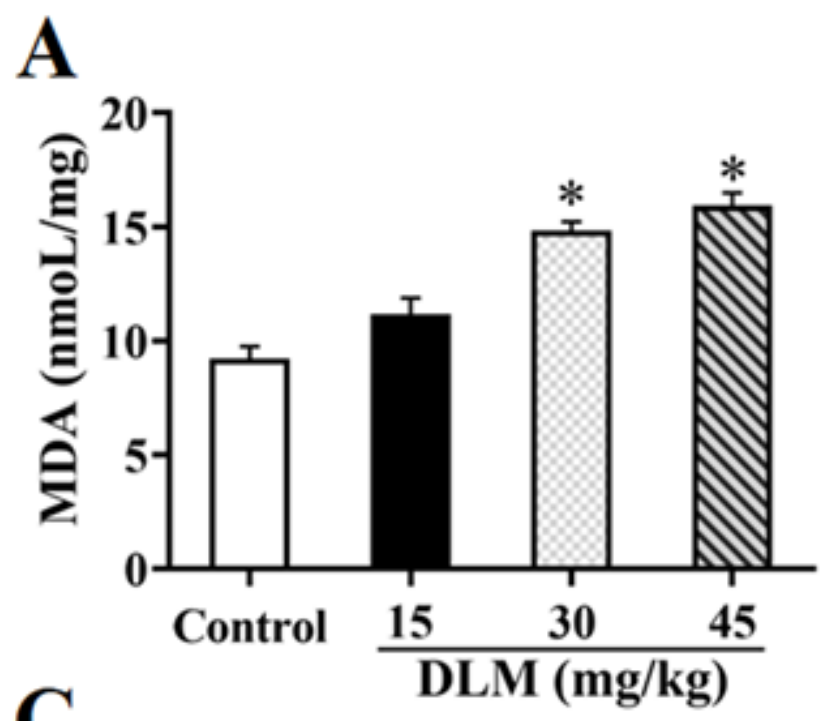

B
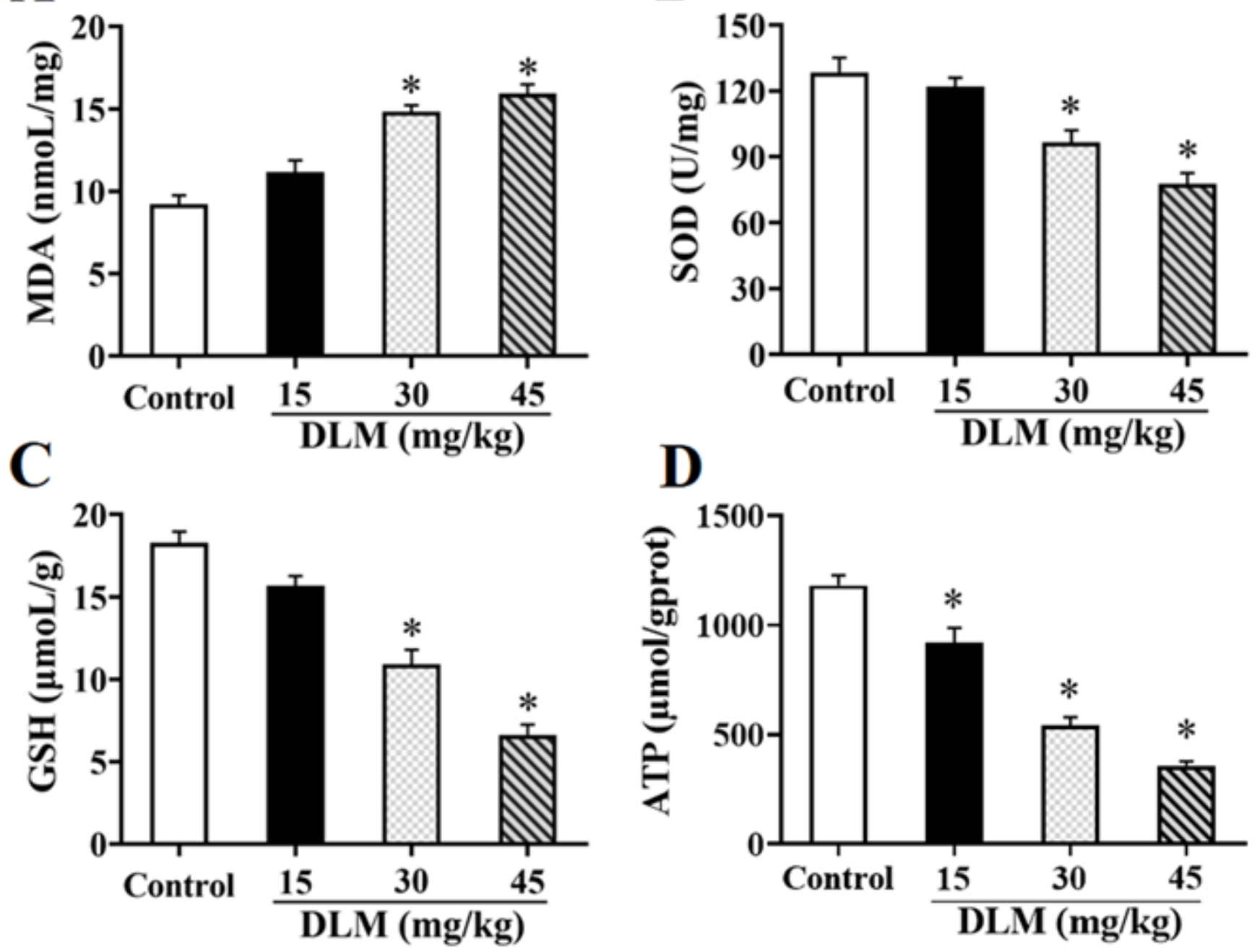

Figure 3

Effect of exposure to DLM on oxidative stress and ATP content changes in quail cerebrum. (A) The concentration of MDA. (B) The activity of SOD. (C) The concentration of GSH. Data are presented as mean \pm SEM $(n=7)$. (D) Changes in ATP content in cerebrum tissue. Values are the mean $\pm S E M, n=7$. * Statistically different $(p<0.05)$ vs control group. 


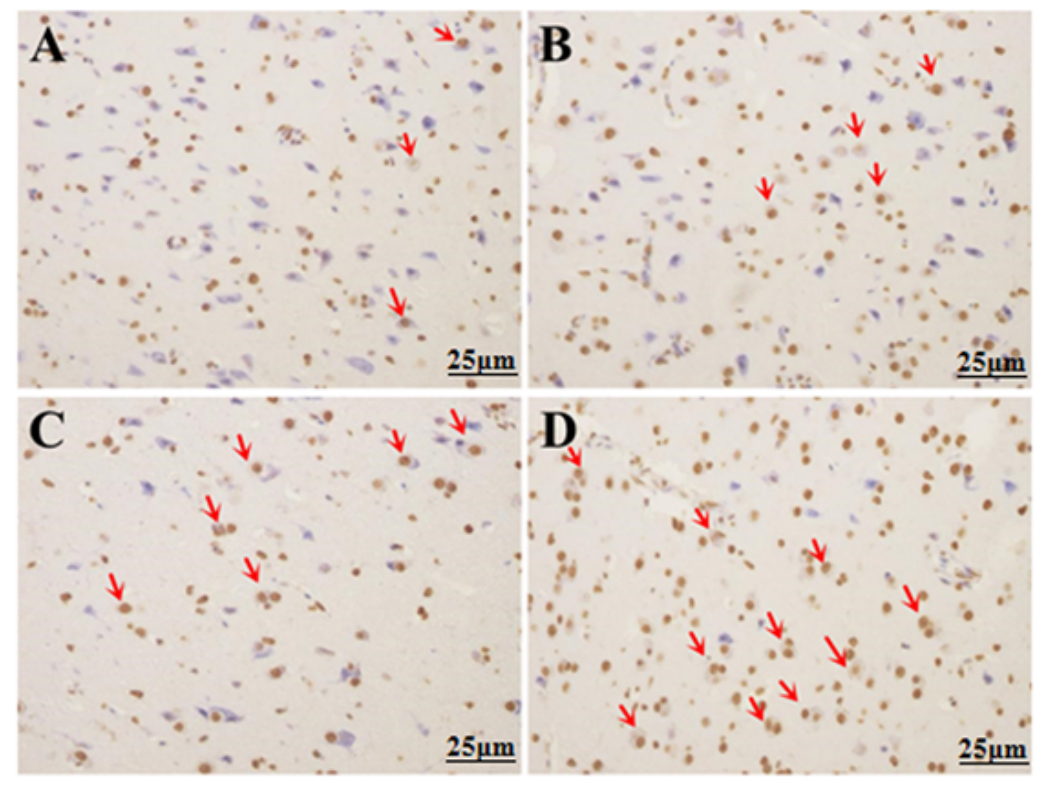

$\mathbf{E}$

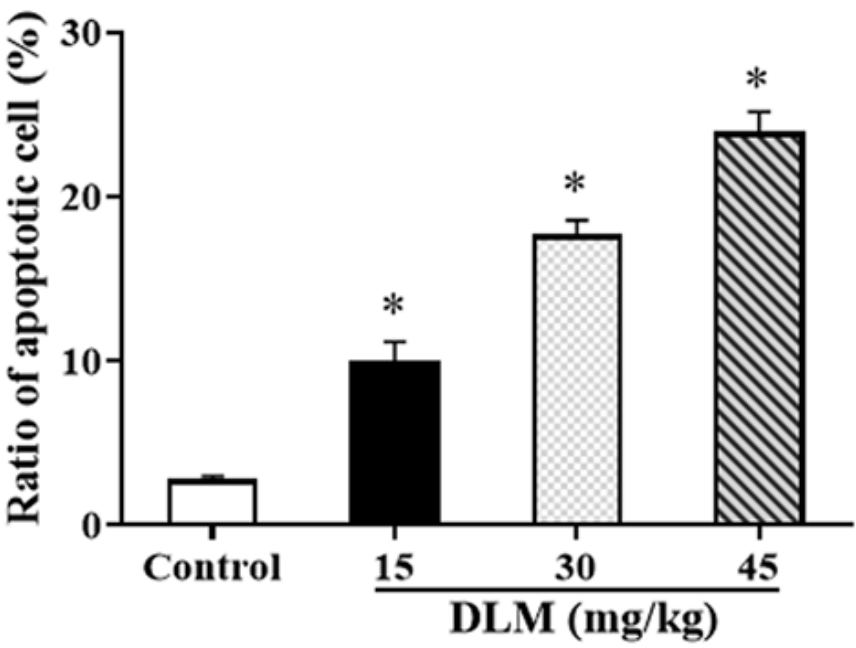

Figure 4

Effect of exposure to DLM on apoptosis in quail cerebrum. (A) Control group. (B) $15 \mathrm{mg} / \mathrm{kg}$ DLM group. (C) $30 \mathrm{mg} / \mathrm{kg}$ DLM group. (D) $45 \mathrm{mg} / \mathrm{kg}$ DLM group (400 $\times$ magnification). (E) The ratio of apoptosis neurons. Data are presented as mean $\pm \operatorname{SEM}(n=5)$. ${ }^{*}$ Statistically different $(p<0.05)$ vs control group. Red arrows indicate apoptotic neurons. 
A
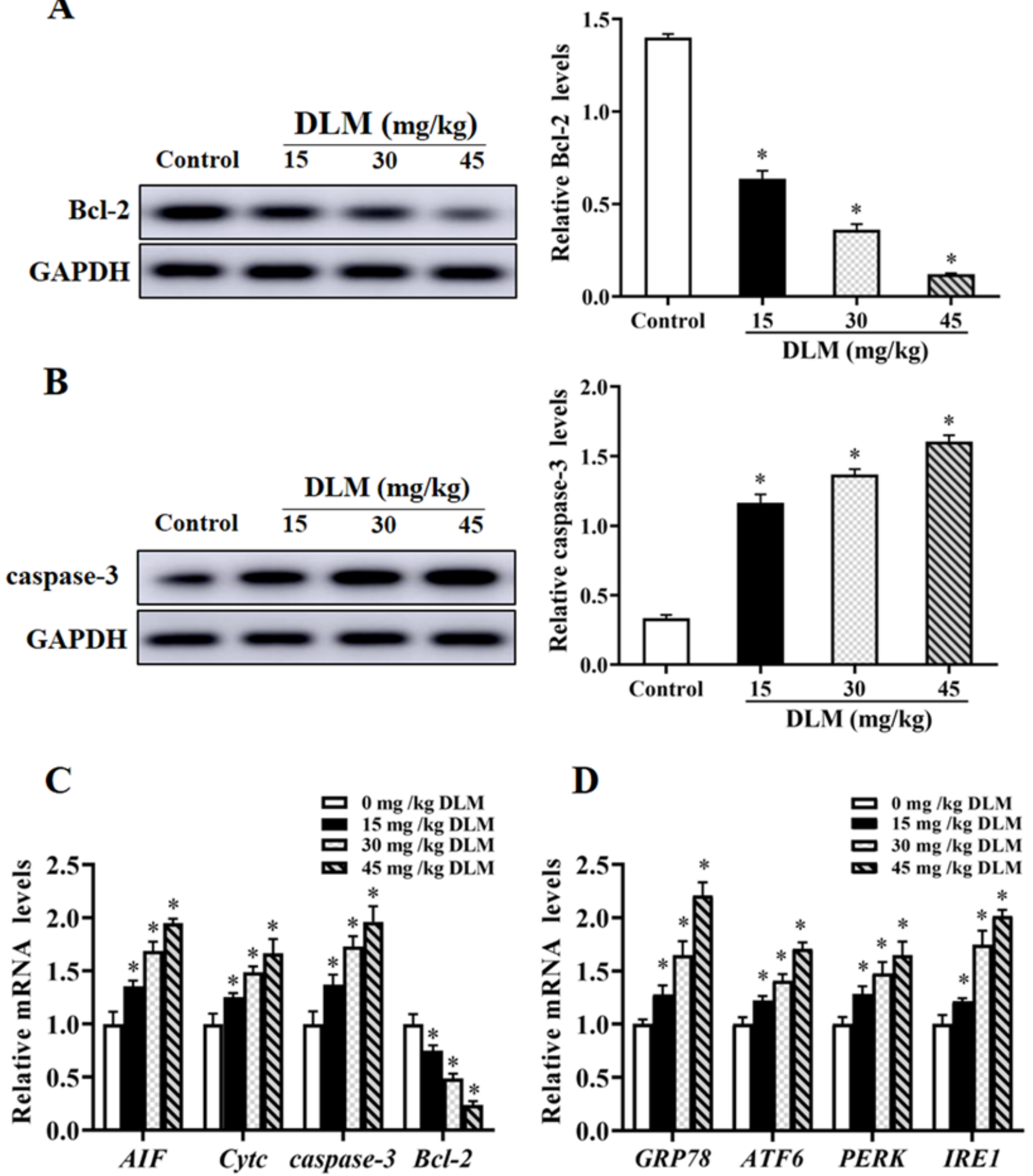

Figure 5

Effect of exposure to DLM on apoptosis-related protein levels and mRNA levels in quail cerebrum. (A) Bcl2 protein expression level. (B) Caspase-3 protein expression level. Data are presented as mean \pm SEM ( $n=$ 4). (C) Mitochondrial pathway-related mRNA of AIF, Cyt C, caspase-3, and Bcl-2 expression levels (D) ER pathway-related mRNA of GRP78, ATF6, PERK, and IRE1 expression levels. Data are presented as mean \pm SEM $(n=7)$. * Statistically different $(p<0.05)$ vs control group. 


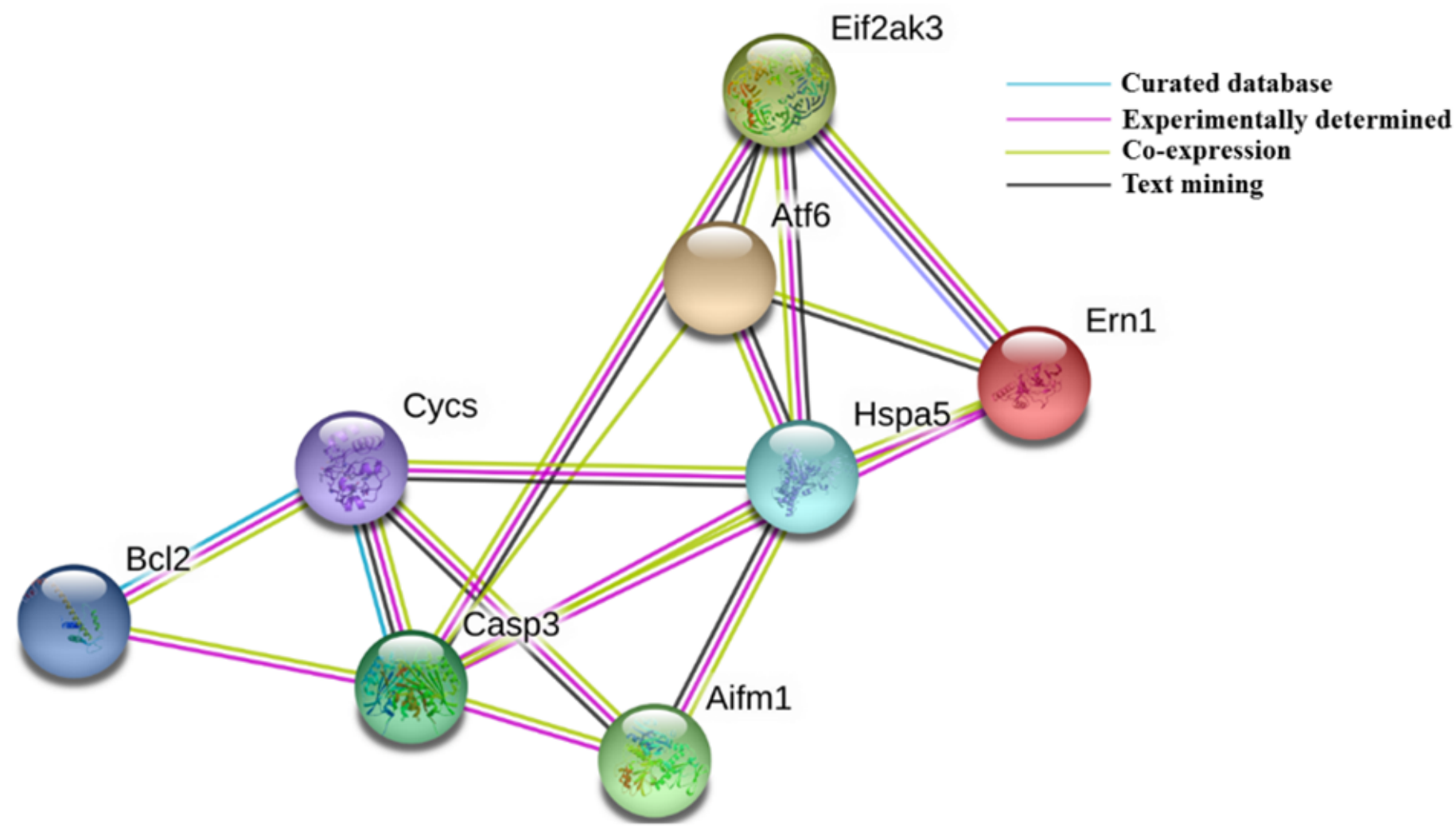

Figure 6

PPI analysis. Protein network of proteins regulated between ER stress-related genes, mitochondrial dynamics-related genes, and apoptosis-related gene expressed in the cerebrum of quail. PERK (Eif2ak3), ATF6 (Atf6), IRE1 (Ern1), GRP78 (Hspa5), AlF (Aifm1), Cyt C (Cycs), caspase-3 (Casp3), and Bcl-2 (Bcl2). 


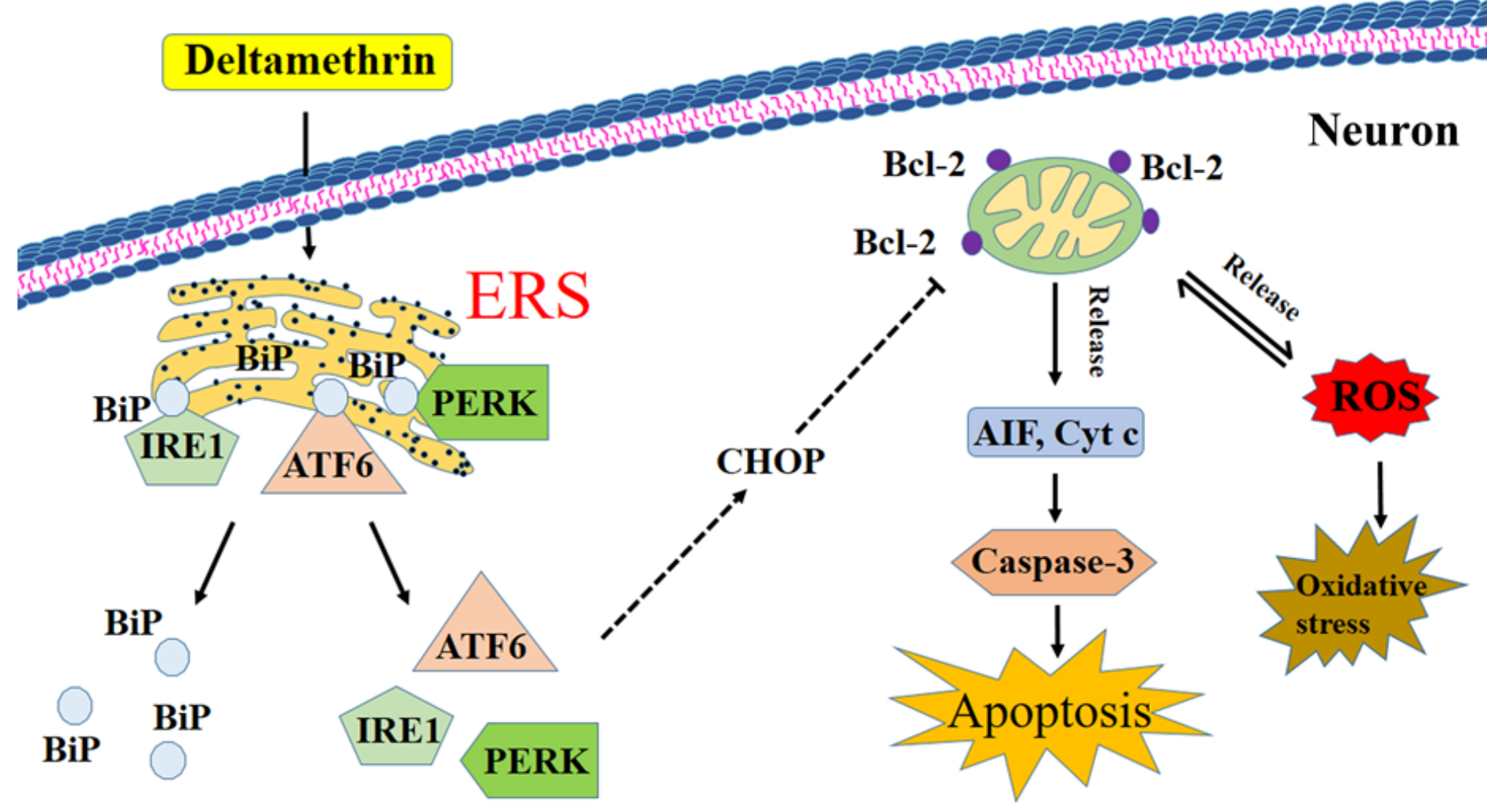

Figure 7

The mechanism on neuronal apoptosis induced by DLM in quail. DLM induces neuronal apoptosis via promoting ER stress and mitochondrial dysfunction. 